\title{
Article \\ Less Carcinogenic Chlorinated Estrogens Applicable to Hormone Replacement Therapy
}

\author{
Yoshinori Okamoto ${ }^{1}{ }^{\oplus}$, Hideto Jinno ${ }^{1}$, Shinji Itoh ${ }^{2}$ and Shinya Shibutani ${ }^{3, *}$ \\ 1 Faculty of Pharmacy, Meijo University, Nagoya 468-8503, Japan; okmt@ccalumni.meijo-u.ac.jp (Y.O.); \\ jinno@meijo-u.ac.jp (H.J.) \\ 2 Faculty of Pharmaceutical Sciences, Hokkaido University of Science, Sapporo 006-8585, Japan; \\ itoh-m33@hus.ac.jp \\ 3 Department of Pharmacological Sciences, State University of New York at Stony Brook, \\ Stony Brook, NY 11794-8651, USA \\ * Correspondence: shinya.shibutani@stonybrook.edu
}

Citation: Okamoto, Y.; Jinno, H.; Itoh, S.; Shibutani, S. Less Carcinogenic Chlorinated Estrogens Applicable to Hormone Replacement Therapy. Int. J. Mol. Sci. 2021, 22, 7222. https:// doi.org/10.3390/ijms22137222

Academic Editors: Giuseppe Carruba and Graeme Williams

Received: 8 June 2021

Accepted: 4 July 2021

Published: 5 July 2021

Publisher's Note: MDPI stays neutral with regard to jurisdictional claims in published maps and institutional affiliations.

Copyright: () 2021 by the authors. Licensee MDPI, Basel, Switzerland. This article is an open access article distributed under the terms and conditions of the Creative Commons Attribution (CC BY) license (https:// creativecommons.org/licenses/by/ $4.0 /)$

\begin{abstract}
Human estrogens prescribed for hormone replacement therapy (HRT) are known to be potent carcinogens. To find safer estrogens, several chlorinated estrogens were synthesized and their carcinogenic potential were determined. A pellet containing either 2-chloro-17 $\beta$-estradiol $\left(2-\mathrm{ClE}_{2}\right)$ or 4-chloro-17 $\beta$-estradiol $\left(4-\mathrm{ClE}_{2}\right)$ was implanted subcutaneously for 52 weeks into August Copenhagen Irish (ACI) rats, a preferred animal model for human breast cancer. $17 \beta$-Estradiol $\left(\mathrm{E}_{2}\right)$ frequently induced mammary tumors while both $2-\mathrm{ClE}_{2}$ and $4-\mathrm{ClE}_{2}$ did not. Their $17 \alpha$-ethinyl forms, thought to be orally active estrogens, were also synthesized. Neither 2-chloro-17 $\alpha$-ethinylestradiol $\left(2-\mathrm{ClEE}_{2}\right)$ nor 4-chloro-17 $\alpha$-ethinylestradiol (4- $\left.\mathrm{ClEE}_{2}\right)$ induced tumors. The less carcinogenic effects were supported by histological examination of mammary glands of $\mathrm{ACI}$ rats treated with the chlorinated estrogens. A chlorine atom positioned at the 2- or 4-position of $\mathrm{E}_{2}$ may prevent the metabolic activation, resulting in reducing the carcinogenicity. $2-\mathrm{ClE}_{2}$ and $4-\mathrm{ClE}_{2}$ administered subcutaneously and 2- $\mathrm{ClEE}_{2}$ and $4-\mathrm{ClEE}_{2}$ given orally to ovariectomized rats all showed uterotrophic potency, albeit slightly weaker than that of $\mathrm{E}_{2}$. Our results indicate that less carcinogenic chlorinated estrogens retaining estrogenic potential could be safer alternatives to the carcinogenic estrogens now in use for HRT.
\end{abstract}

Keywords: estrogen; chlorination; mammary tumor; uterotrophic activity; hormone replacement therapy; DNA damage

\section{Introduction}

Human estrogens are used in hormone replacement therapy (HRT) to alleviate menopausal symptoms and protect against osteoporosis [1,2]. Unfortunately, long-term HRT increases the incidence of breast [3-6] and endometrial cancers [7]. The risk of these cancers is correlated with the duration of HRT [4-6,8]. The mechanism underlying estrogen-induced carcinogenesis has not been fully explored, but both proliferative effects mediated through the estrogen receptor and/or DNA damage induced by human estrogen metabolites are significant factors in the process [9-11].

DNA damage has been detected in the tissues of rodents treated with human estrogens [12-15]. Human estrogens are primarily metabolized by cytochrome P450 enzymes to form 2- and 4-hydroxyestrogens (2- and 4-OHE) [16] (Figure 1). The catecholestrogens are oxidized further to 2,3-quinone and / or 3,4-quinone by P450 enzymes or peroxidase [16-18]. The 2,3-quinone of 2-OHE reacts with DNA to form 2-OHE- $N^{2}-\mathrm{dG}$ and 2-OHE- $N^{6}-\mathrm{dA}$ [19], which are potentially mutagenic [20]. The 3,4-quinone of 4-OHE reacts with $\mathrm{dA}$ and dG to form 4-OHE- $1(\alpha, \beta)-N^{3}-\mathrm{dA}$ and 4 -OHE- $1(\alpha, \beta)-N^{7}-\mathrm{dG}$, which are readily depurinated $[19,21]$. The resulting apurinic sites are mutagenic lesions [22], contributing to the initiation of cancer. During redox cycling, 2,3-quinone and/or 3,4-quinone are reduced back to their catecholestrogens. In the reduction reactions, free radicals produced cause 
oxidative DNA damage such as 8-oxo-7,8-dihydro-2'-deoxyguanosine [23], which has been detected in mammary DNA obtained from breast cancer patients [24]. Thus, DNA damages induced by human estrogens are capable of initiating breast and endometrial cancer.

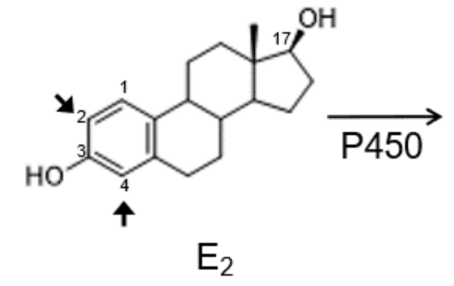

$\uparrow$ Chlorinated sites



Figure 1. Proposed oxidative mechanism of chlorinated estrogens.

The August Copenhagen Irish (ACI) rat strain has been used as a preferred animal model for studying human sporadic breast cancer. ACI rats have a very low incidence (11\% over 3 years) of spontaneous mammary tumors $[25,26]$, which is advantageous for accurately evaluating their tumorigenicity. Indeed, $\mathrm{E}_{2}$ (the structure in Figure 2) [25-27] and $17 \alpha$-ethinylestradiol $\left(\mathrm{EE}_{2}\right)$ [28] were demonstrated to induce mammary tumors. Therefore, women receiving human estrogens for HRT may have a higher risk of developing breast and reproductive cancers.<smiles>CC12CCC3c4ccc(O)cc4CCC3C1CCC2O</smiles>

$E_{2}$<smiles>C#C[C@]1(O)CCC2C3CCc4cc(O)ccc4C3CCC21C</smiles>

$\mathrm{EE}_{2}$<smiles>CC12CCC3c4cc(Cl)c(O)cc4CCC3C1CCC2O</smiles>

$2-\mathrm{ClE}_{2}$<smiles>C#C[C@]1(O)CCC2C3CCc4cc(O)c(Cl)cc4C3CCC21C</smiles>

$2-$ CIEE $_{2}$<smiles>CC12CCC3c4ccc(O)c(Cl)c4CCC3C1CCC2O</smiles>

4-ClE<smiles>C=C[C@]1(O)CCC2C3CCc4c(ccc(O)c4Cl)C3CCC21C</smiles>

4-CIEE ${ }_{2}$

Figure 2. Structures of $\mathrm{E}_{2}$ and $\mathrm{EE}_{2}$ and their chlorinated compounds.

In the present study, to prevent the metabolic activation of estrogens, a hydrogen atom at the 2- or 4-position of human estrogen was replaced by a chlorine atom. The tumorigenic and estrogenic potentials of the synthesized chlorinated estrogens (Figure 2), 2-chloro-17 $\beta$ estradiol (2- $\left.\mathrm{ClE}_{2}\right)$ and 4-chloro- $17 \beta$-estradiol $\left(4-\mathrm{ClE}_{2}\right)$, were determined using rat models. Because $E_{2}$ is inactivated when taken orally, the $17 \alpha$-ethinyl formula is used for oral 
treatment $[29,30]$. The chlorinated $17 \alpha$-ethinyl compounds, 2-chloro-17 $\alpha$-ethinylestradiol $\left(2-\mathrm{ClEE}_{2}\right)$ and 4-chloro-17 $\alpha$-ethinylestradiol $\left(4-\mathrm{ClEE}_{2}\right)$, were also synthesized and subjected to measure their tumorigenic and estrogenic potentials.

\section{Results}

\subsection{Evidence of Mammary Tumors}

Development of mammary tumors in ACI rats implanted with a pellet containing $E_{2}$ or a chlorinated estrogen was monitored by palpation once a week for 52 weeks. In rats administered $E_{2}(1.25 \mathrm{mg})$, palpable mammary tumors appeared around 38 weeks after pellet implantation; the cumulative incidence of the tumors was $80 \%(4 / 5)$ after 52 weeks (Figure 3 and Table 1). With $2.5 \mathrm{mg} \mathrm{E}_{2}$, mammary tumors appeared earlier, at 24 weeks, although the cumulative tumor incidence was 90\% (9/10)-i.e., almost same as that observed with $1.25 \mathrm{mg} \mathrm{E}_{2}$. When $5.0 \mathrm{mg} \mathrm{E}_{2}$ was implanted, severe loss of body weight occurred within several weeks; therefore, the experiment with $5.0 \mathrm{mg} \mathrm{E}_{2}$ was terminated. Mammary tumors were confirmed by pathological examination as performed previously $[27,31]$. The body weight of rats treated with the following chlorinated estrogen increased as observed with the untreated rats. When dissected ACI rats treated with chlorinated estrogens at the end of experiment, no significant abnormality was observed in other organs including ovary and uterus. Among the 6 rats treated with $2.5 \mathrm{or} 5.0 \mathrm{mg}$ $2-\mathrm{ClE}_{2}$ or $4-\mathrm{ClE}_{2}$, no palpable mammary tumors were observed even after 52 weeks, as shown in the untreated rats (Figure 3 and Table 1 ). The $17 \alpha$-ethinyl compounds, 2-ClEE 2 and $4-\mathrm{ClEE}_{2}$, also did not induce the tumors (Table 1). The data obtained by the $17 \alpha$-ethinyl formula may support and strengthen the non-tumor evidence of $2-\mathrm{ClE}_{2}$ and $4-\mathrm{ClE}_{2}$.



Figure 3. Cumulative incidence of mammary tumors in chlorinated estrogen-treated rats. Development of mammary tumors in ACI rats implanted with placebo $(n=5), \mathrm{E}_{2}$ [1.25 $\left.\mathrm{mg}(n=5), 2.5 \mathrm{mg}(n=10)\right], 2-\mathrm{ClE}_{2}$ [5.0 $\left.\mathrm{mg}(n=6)\right]$, or 4-ClE 2 $[5.0 \mathrm{mg}(n=6)]$ pellets was monitored once a week for 52 weeks.

\subsection{Histological Examination of Mammary Glands}

Mammary whole-mounts of chlorinated estrogen-treated ACI rats were subjected to histological examination. With $\mathrm{E}_{2}$ (Figure $4 \mathrm{~B}$ ), extension of the mammary glands, branching of the ducts, and the number of end buds and alveoli were all increased. Premalignant 
lesions such as acinar hyperplasia was also observed in whole-mount preparations. In contrast, enlargement of the mammary glands in rats treated with 2- $\mathrm{ClE}_{2}$ (Figure $4 \mathrm{C}$ ) or 4$\mathrm{ClE}_{2}$ (Figure $4 \mathrm{D}$ ) was much less than that produced by $\mathrm{E}_{2}$. Mammary glands of rats treated with the $17 \alpha$-ethinyl forms, 2-ClEE 2 (Figure 4E) and 4-ClEE 2 (Figure 4F), showed similar histological results as those treated with $2-\mathrm{ClE}_{2}$ and $4-\mathrm{ClE}_{2}$, respectively. No precancerous lesions were detected in rats treated with any chlorinated estrogens. Neither enlargement of the mammary glands nor premalignant lesions were detected in the vehicle-treated control ACI rats (Figure 4A).

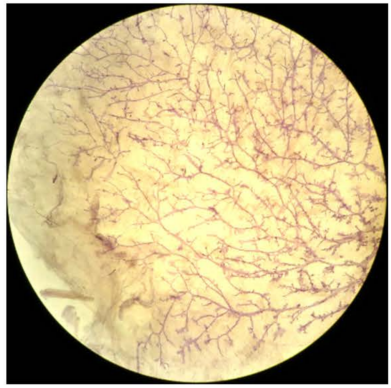

(A) Control

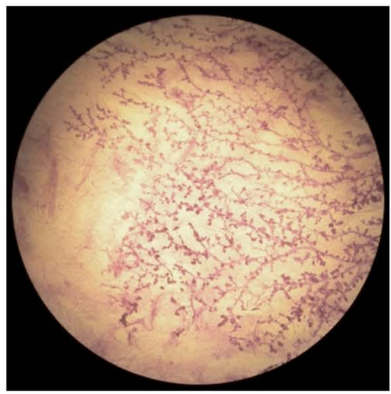

(C) $2-\mathrm{ClE}_{2}$

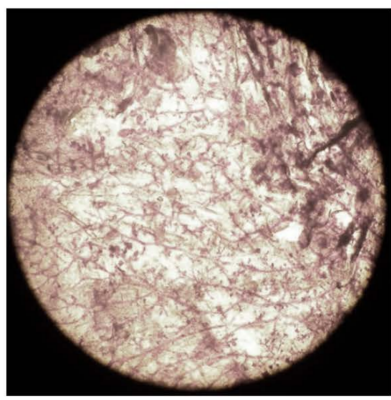

(E) $2-\mathrm{CIEE}_{2}$

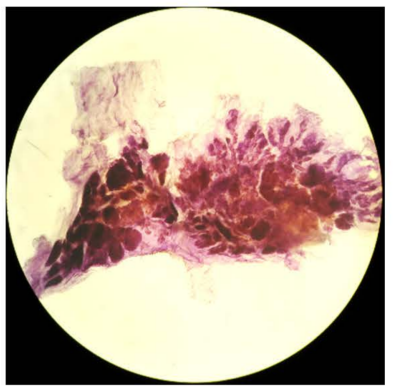

(B) $\mathrm{E}_{2}$

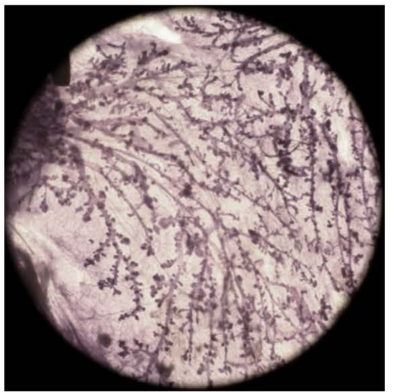

(D) $4-\mathrm{ClE}_{2}$

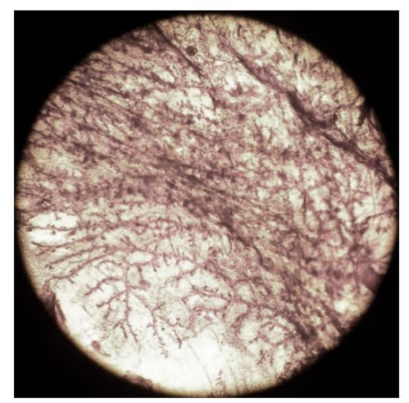

(F) $4-\mathrm{ClEE}_{2}$

Figure 4. Morphological examination of mammary glands of chlorinated estrogen-treated rats. Mammary glands were collected from ACI rats at the end of the experiments. Mammary tissue of ACI rats implanted with placebo (A), $\mathrm{E}_{2}(2.5 \mathrm{mg})(\mathbf{B}), 2-\mathrm{ClE}_{2}(5.0 \mathrm{mg})(\mathbf{C}), 4-\mathrm{ClE}_{2}(5.0 \mathrm{mg})$ (D), $2-\mathrm{ClEE}_{2}(5.0 \mathrm{mg})(\mathbf{E})$, or 4-ClEE $2(5.0 \mathrm{mg})(\mathbf{F})$ and stained with hematoxylin (magnification $\left.10 \times\right)$.

\subsection{Uterotrophic Activity of Chlorinated Estrogens}

To determine the estrogenic potential of chlorinated estrogens, 2- $\mathrm{ClE}_{2}$ or $4-\mathrm{ClE}_{2}$ was administered subcutaneously for 3 days to OVX-rats (Figure 5A). $\mathrm{E}_{2}(3.0 \mu \mathrm{g})$, as a positive control, increased the uterine length and thickness. With $2-\mathrm{ClE}_{2}$ or $4-\mathrm{ClE}_{2}$ at a dose molar equivalent of $E_{2}(3.0 \mu \mathrm{g})$, no increase in uterine size was observed. With a 10-times molar dose $(34 \mu \mathrm{g})$, both $2-\mathrm{ClE}_{2}$ and $4-\mathrm{ClE}_{2}$ promoted uterine weight gain. The uterine weight of OVX-rats treated with $\mathrm{E}_{2}$ was $0.99 \mathrm{mg} / \mathrm{g}$ bw and that of untreated OVX-rats was $0.39 \mathrm{mg} / \mathrm{g}$ bw. Both $2-\mathrm{ClE}_{2}(0.67 \mathrm{mg} / \mathrm{g} \mathrm{bw})$ and $4-\mathrm{ClE}_{2}(0.93 \mathrm{mg} / \mathrm{g} \mathrm{bw})$ showed significant uterotrophic activity. 


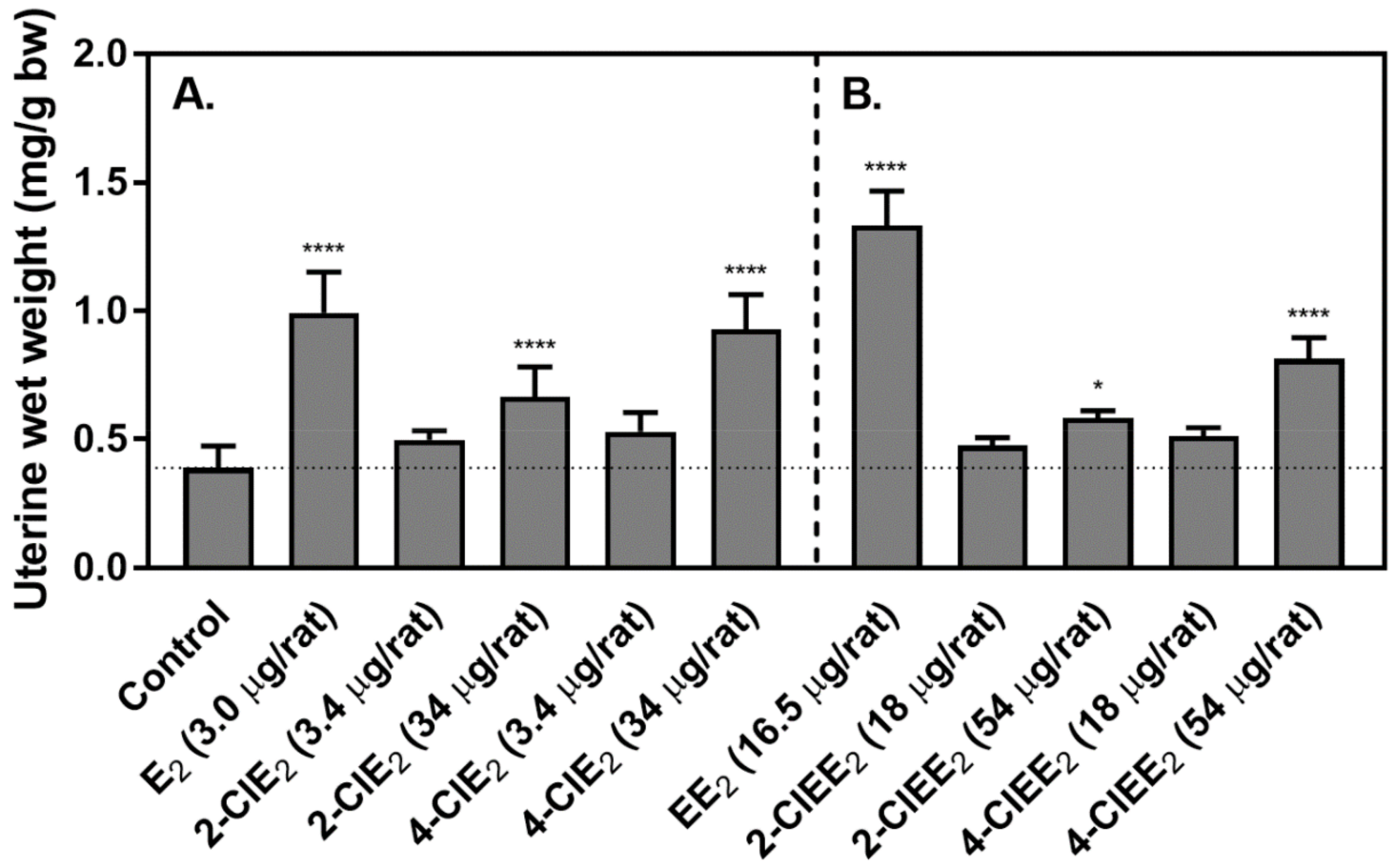

Figure 5. Uterotrophic potential of chlorinated estrogens on OVX-rats. (A) OVX-rats (4 rats/group) were treated subcutaneously for 3 days with $2-\mathrm{ClE}_{2}$ (3.4 or $34 \mu \mathrm{g} / \mathrm{rat} /$ day) or $4-\mathrm{ClE}_{2}(3.4 \mathrm{or} 34 \mu \mathrm{g} / \mathrm{rat} / \mathrm{day})$. The rats treated with $\mathrm{E}_{2}$ $(3.0 \mu \mathrm{g} / \mathrm{rat} /$ day) were used as positive controls. The negative control rats received vehicle only. (B) OVX-rats (4 rats/group) were treated orally for 3 days with $2-\mathrm{ClEE}_{2}$ (18 or $54 \mu \mathrm{g} / \mathrm{rat} /$ day) or $4-\mathrm{ClE}_{2}$ (18 or $54 \mu \mathrm{g} / \mathrm{rat} /$ day). The rats treated with $\mathrm{EE}_{2}$ $(16.5 \mu \mathrm{g} / \mathrm{rat} /$ day) were used as positive controls. On day 4 , uterine wet-weight/bw ratios were calculated and compared to that obtained for OVX-rats that received vehicle, as described in Materials and Methods. Statistical analysis (one-way ANOVA with Tukey's post hoc test) was performed for multiple comparisons to evaluate differences; ${ }^{*}, p<0.05$ (control vs. $\left.2-\mathrm{ClEE}_{2}(54 \mu \mathrm{g} / \mathrm{rat})\right) ;{ }^{* * * *}, p<0.0001$ (control vs. $\mathrm{E}_{2}(3.0 \mu \mathrm{g} / \mathrm{rat}), 2-\mathrm{ClE}_{2}(34 \mu \mathrm{g} / \mathrm{rat}), 4-\mathrm{ClE}_{2}(34 \mu \mathrm{g} / \mathrm{rat}), \mathrm{EE}_{2}(16.5 \mu \mathrm{g} / \mathrm{rat}), \mathrm{or}$ $\left.4-\mathrm{ClE}_{2}(54 \mu \mathrm{g} / \mathrm{rat})\right)$.

Table 1. Incidence of mammary tumors in ACI rats implanted with a chlorinated estrogen.

\begin{tabular}{cccc}
\hline Compound & $\begin{array}{c}\text { Dose } \\
\text { (mg/pellet) }\end{array}$ & $\begin{array}{c}\text { Cumulative Incidence } \\
\text { (No. of Rats) }\end{array}$ & $\begin{array}{c}\text { Percentage of Rats } \\
\text { with Tumors (\%) }\end{array}$ \\
\hline Control & - & $0 / 6$ & 0 \\
\hline \multirow{2}{*}{$\mathrm{E}_{2}$} & 1.25 & $4 / 5$ & 80 \\
& 2.5 & $9 / 10$ & 90 \\
& 5.0 & $-\mathrm{b}$ & $\mathrm{b}$ \\
\hline \multirow{2}{*}{$2-\mathrm{ClE}_{2}$} & 2.5 & $0 / 6$ & 0 \\
\cline { 2 - 4 } & 5.0 & $0 / 6$ & 0 \\
\hline \multirow{2}{*}{$4-\mathrm{ClE}_{2}$} & 2.5 & $0 / 6$ & 0 \\
\cline { 2 - 4 } $2-\mathrm{ClEE}_{2}$ & 5.0 & $0 / 6$ & 0 \\
\hline \multirow{2}{*}{$4-\mathrm{ClEE}_{2}$} & 2.5 & $0 / 5$ & 0 \\
\hline & 5.0 & $0 / 6$ & 0 \\
\hline & 2.5 & $0 / 5$ & 0 \\
\hline
\end{tabular}

$\bar{a}$ Data are expressed as number of tumor-induced rats per total number of rats used. ${ }^{b}$ Due to the severe loss of body weight, the experiment was terminated.

Since $17 \alpha$-ethinyl formula is designed for oral treatment, the uterotrophic potency of $2-\mathrm{ClEE}_{2}$ or $4-\mathrm{ClEE}_{2}$ was determined after given orally for 3 days (Figure $5 \mathrm{~B}$ ). At the dose 
molar equivalent to $\mathrm{EE}_{2}(16.5 \mu \mathrm{g})$, neither $2-\mathrm{ClEE}_{2}$ nor $4-\mathrm{ClEE}_{2}$ produced an increase in uterine weight. At the 3-times molar dose $(54 \mu \mathrm{g})$, a significant increase of uterine weight was measured. The uterine weight of OVX-rats treated with $\mathrm{EE}_{2}$ was $1.33 \mathrm{mg} / \mathrm{g}$ bw. Both 2$\mathrm{ClEE}_{2}(0.58 \mathrm{mg} / \mathrm{g} \mathrm{bw})$ and $4-\mathrm{ClEE}_{2}(0.81 \mathrm{mg} / \mathrm{g} \mathrm{bw})$ showed significant uterotrophic activity.

\section{Discussion}

Trace amounts of chlorinated estrogens are produced in the environment as byproducts of reactions between estrogens and hypochlorous acid in sewage treatment plants [32,33]; their estrogenic potency was detected using an in vitro yeast two-hybrid assay with the estrogen receptor $\alpha$. However, the biological properties of chlorinated estrogens in vivo are poorly understood. In the present study, the carcinogenic potential of chlorinated estrogens was determined using estrogen-sensitive ACI rats implanted with their pellets for one year. As reported previously $[25,27,31], \mathrm{E}_{2}(1.25 \mathrm{mg}$ or $2.5 \mathrm{mg})$ was a potent inducer of mammary tumors (Figure 3 and Table 1$)$. In contrast, $2-\mathrm{ClE}_{2}$ and $4-\mathrm{ClE}_{2}(2.5 \mathrm{mg}$ and $5.0 \mathrm{mg}) \mathrm{did}$ not induce mammary tumors even after one year of treatment. The $5.0 \mathrm{mg}$ of chlorinated estrogens was 4-times higher dose than $1.25 \mathrm{mg} \mathrm{E}_{2}$ that induced mammary tumors [27], indicating that the chlorinated estrogens appear to be less carcinogenic. The $17 \alpha$-ethinyl form of $\mathrm{E}_{2}\left(\mathrm{EE}_{2}\right)$ was reported by another research group [28,34], to be a strong inducer of mammary tumors in ACI rats. However, both $2-\mathrm{ClEE}_{2}$ and $4-\mathrm{ClEE}_{2}$ did not develop mammary tumors (Table 1). The less carcinogenic potential observed for chlorinated $\mathrm{E}_{2}$ or $\mathrm{EE}_{2}$ was supported by histological examination of mammary glands of chlorinated estrogen-treated ACI rats (Figure 4).

In our recent study [27], 2-fluoro-17 $\beta$-estradiol $\left(2-\mathrm{FE}_{2}\right)$ did not induce mammary tumors whereas 4-fluoro-17 $\beta$-estradiol $\left(4-\mathrm{FE}_{2}\right)$ did. Because of the carbon-fluorine bond strength [35], fluorination inhibits metabolic hydroxylation of $E_{2}$. A fluorine at the 2position of $\mathrm{E}_{2}$ prevents 2-hydroxylation, resulting in preferential 4-hydroxylation [36]. On the other hand, a fluorine at the 4-position of $\mathrm{E}_{2}$ prevents 4-hydroxylation, resulting in preferential 2-hydroxylation. These results suggest that the development of mammary tumors might occur through the 2-hydroxylation of 4- $\mathrm{FE}_{2}$, not through the 4-hydroxylation of 2-FE 2 . Surprisingly, unlike $4-\mathrm{FE}_{2}, 4-\mathrm{ClE}_{2}$ did not induce mammary tumors. Because a chlorine atom has greater steric hindrance and electron-withdrawing power than a fluorine atom, chlorine modification of estrogen may be more effective to diminish its carcinogenicity. The bulky chlorine atom may affect to inhibit the hydroxylation at both the 2- and 4-positions of estrogens. In addition, the resulting catecholestrogens may hardly be oxidized by the bulky chlorine atom to form their reactive quinones that can damage DNA $[19,21,23]$.

To evaluate such evidence, the metabolites of halogenated estrogen absorbed into body should be determined. Using a radioimmunoassay (RIA), the serum $\mathrm{E}_{2}$ level in ACI rats treated with $3.0 \mathrm{mg} \mathrm{E}_{2}$ pellet was reported to be less than $175 \mathrm{pg} / \mathrm{mL}$ [25]. Unfortunately, the RIA used for $E_{2}$ is not applicable to assay other estrogens. A newly sensitive method is required to be developed for determining such low level of halogenated estrogens and their metabolites, especially in mammary and reproductive organs.

To determine whether the chlorinated estrogens have estrogenic potency, the uterotrophic activity was measured as an indicator after treating OVX-rats subcutaneously for 3 days with $2-\mathrm{ClE}_{2}$ or $4-\mathrm{ClE}_{2}$. Significant uterotrophic activity was observed when treated with $34 \mu \mathrm{g}$ of either $2-\mathrm{ClE}_{2}$ or $4-\mathrm{ClE}_{2}$ (Figure $5 \mathrm{~A}$ ). The body weight of OVX-rats was $180 \mathrm{~g}$; therefore, the daily dose $34 \mu \mathrm{g} /$ rat was $189 \mu \mathrm{g} / \mathrm{kg} /$ day. Because the body weight of ACI rats treated for 52 weeks with a $5.0 \mathrm{mg}$ chlorinated estrogen was $\sim 80 \mathrm{~g}$, the daily dose was estimated to be $172 \mu \mathrm{g} / \mathrm{kg} /$ day that was similar to that (189 $\mu \mathrm{g} / \mathrm{kg} /$ day $)$ of OVX-rats treated with $34 \mu \mathrm{g}$ chlorinated estrogens. This indicated that the dose appearing high estrogenic potential may not always have carcinogenic potency.

$\mathrm{E}_{2}$ is generally given by parenteral treatment because if taken by mouth it is inactivated quickly. On the other hand, the $17 \alpha$-ethinyl form can be absorbed more efficiently by the body and thus has a higher bioavailability after oral delivery [29,30]. In OVX-rats treated 
orally with either 2-ClEE 2 or 4- $\mathrm{ClEE}_{2}$, both chlorinated compounds showed significant uterotrophic activity (Figure 5B). Although the chlorinated estrogens required higher doses than $\mathrm{EE}_{2}$, they provided effective estrogenic potency by oral treatment.

In our previous paper [27], both non-carcinogenic 2- $\mathrm{FE}_{2}$ and carcinogenic 4- $\mathrm{FE}_{2}$ appeared similar uterotrophic potency, indicating that estrogenic potential may not be the sole factor driving mammary tumorigenesis. 2- $\mathrm{FE}_{2}$ retaining estrogenic potential has shown to be a safer alternative for HRT. However, the difficult isolation process of 2- $\mathrm{FE}_{2}$ from 4- $\mathrm{FE}_{2}$ [37] requires the development of a specific separation method. On the other hand, both $2-\mathrm{ClE}_{2}$ and $4-\mathrm{ClE}_{2}$ having estrogenic potency did not present carcinogenic potency. If no separation method is established, the mixture of chlorinated estrogens may be used similarly to a combination tablet currently prescribed for HRT.

In conclusion, chlorinated estradiol derivatives retaining estrogenic potential were less mammary carcinogenic. Such chlorinated estrogens could be used as safer alternatives to carcinogenic estrogens now in use for HRT.

\section{Materials and Methods}

\subsection{Chemicals}

$\mathrm{E}_{2}$ [estra-1,3,5(10)-triene-3,17 $\beta$-diol], $\mathrm{EE}_{2}$ [17 $\alpha$-ethinylestra-1,3,5(10)-triene-3,17 $\beta$-diol] and cholesterol were purchased from Fujifilm Wako Pure Chemical Corp. (Osaka, Japan). Trichloroisocyanuric acid (TCCA) was purchased from Tokyo Chemical Industry Co., Ltd. (Tokyo, Japan).

\subsection{Synthesis of Chlorinated Estrogens}

2- $\mathrm{ClE}_{2}, 4-\mathrm{ClE}_{2}, 2-\mathrm{ClEE}_{2}$, and 4-ClEE 2 were synthesized in good yield by a following modification of the established procedure [38]. TCCA $(0.84 \mathrm{~g})$ was added to an ice-cooled solution of the $\mathrm{E}_{2}(2.0 \mathrm{~g})$ in acetonitrile $(100 \mathrm{~mL})$ and stirred for $1 \mathrm{hr}$. The reaction mixture was extracted with ethyl acetate. The organic layer was washed with $5 \%$ aqueous sodium hydrogen sulphite, $5 \%$ aqueous sodium carbonate and water, and evaporated. An ethanol solution $(40 \mathrm{~mL})$ of the residue was treated with sodium borohydride $(0.67 \mathrm{~g})$, and stirred at room temperature for $20 \mathrm{~min}$. The reaction mixture was extracted with ethyl acetate. The organic layer was evaporated to give a residue, which was submitted to preparative HPLC equipped with an ODS column to given pure products of $2-\mathrm{ClE}_{2}(0.22 \mathrm{~g}, 10 \%), 4-\mathrm{ClE}_{2}(0.26 \mathrm{~g}$, $11 \%)$, and 2,4-dichloro- $17 \beta$-estradiol (2,4- $\left.\mathrm{diClE}_{2} ; 0.22 \mathrm{~g}, 9 \%\right)$. Using the same procedure as described for chlorination of $\mathrm{E}_{2}$, treatment of $\mathrm{EE}_{2}(2.0 \mathrm{~g})$ with TCCA $(0.80 \mathrm{~g})$ gave 2$\mathrm{ClEE}_{2}(0.21 \mathrm{~g}, 9 \%), 4-\mathrm{ClEE}_{2}(0.26 \mathrm{~g}, 12 \%)$, and 2,4-diClEE $2(0.30 \mathrm{~g}, 12 \%)$. Preparative HPLC conditions were as follows. Pump, model SP-22 (Tokyo Rikakikai, Co., LTD., Tokyo, Japan); detector, model 8011 (Tosoh Corp., Tokyo, Japan) at $270 \mathrm{~nm}$; column, two $22 \mathrm{~mm}$ i.d. $\times 300 \mathrm{~mm}$ glass columns containing $\mu$-Bondasphere $15 \mu \mathrm{m}$ (Waters, Milford, MA, USA) were joined together; mobile phase, methanol-water $(80: 20, \mathrm{v} / \mathrm{v})$; flow rate, $5.0 \mathrm{~mL} / \mathrm{min}$. By HPLC/UV or NMR analysis, the purity of chlorinated estrogens was determined to be $>99 \%$.

\subsection{Tumorigenesis of Chlorinated Estrogens}

The animal studies were approved by an ethics committee of Faculty of Pharmacy, Meijo University. All procedures with animals were conducted in compliance with the Guidelines for Proper Conduct of Animal Experiments (Science Council of Japan). Rats (ACI, 5-week-old females, Harlan) were given water and food ad libitum and kept on a 12-h light/dark cycle throughout the study. Following an established protocol for $\mathrm{E}_{2}[25,27,31]$, after one week of acclimation, the following pellet was implanted under the dorsal skin with light isoflurane anesthesia: $2-\mathrm{ClE}_{2} 2.5 \mathrm{mg}$ or $5.0 \mathrm{mg}$ ( $n=6$ rats), $4-\mathrm{ClE}_{2} 2.5 \mathrm{mg}$ or $5.0 \mathrm{mg}$ $(n=6), 2-\mathrm{ClEE}_{2} 2.5 \mathrm{mg}$ or $5.0 \mathrm{mg}(n=5-6)$, or $4-\mathrm{ClEE}_{2} 2.5 \mathrm{mg}$ or $5.0 \mathrm{mg}(n=5)$ in cholesterol (15.0 or $17.5 \mathrm{mg}$ ), and $20 \mathrm{mg}$ cholesterol alone $(n=6)$ as the negative control. ACI rats implanted with $\mathrm{E}_{2} 1.25 \mathrm{mg}(n=5), 2.5 \mathrm{mg}(n=10)$, or $5.0 \mathrm{mg}(n=5)$ pellet were used as the positive control. Development of mammary tumors was monitored by palpation once a 
week for 52 weeks. At the end of experiments, rats were euthanized by $\mathrm{CO}_{2}$ asphyxiation. Pathological determination of mammary tumors was performed following the established procedure in our laboratory [27,31].

\title{
4.4. Mammary Whole-Mount Preparation and Morphometric Analysis
}

Rats were euthanized under isoflurane anesthesia. Following an established protocol $[27,31]$, the skin containing mammary glands was collected and fixed in $10 \%$ neutralbuffered formalin for at least 3 days. The mammary glands were then dissected free from the skin and processed as a whole mount. The glands were defatted in ethanol, acetone, chloroform, and ethanol again for at least 3 days in each solvent. After rehydration, the glands were stained with hematoxylin and washed with distilled water. The stained glands were cleaned up manually by viewing through a stereomicroscope, dehydrated in ethanol, cleared in xylene and mounted. Photographs were taken using a digital camera (Olympus, Tokyo, Japan) mounted on a stereomicroscope (Stemi SV11, Carl Zeiss, Jena, Germany).

\subsection{Determination of Uterotrophic Potential}

The uterotrophic activity of chlorinated estrogens was determined by following the protocol reported previously [27,31]. Briefly, OVX-rats (Sprague-Dawley, 6-week-old females, Japan SLC, Inc., Shizuoka, Japan; 4 rats/dose) were treated subcutaneously for 3 days with $2-\mathrm{ClE}_{2}$ or $4-\mathrm{ClE}_{2}$. A dose one- or ten-times molar equivalent to $\mathrm{E}_{2}$ $\left(3.0 \mu \mathrm{g} / \mathrm{rat} /\right.$ day) was used; 3.4 or $34 \mu \mathrm{g} / \mathrm{rat} /$ day for $2-\mathrm{ClE}_{2}$ or $4-\mathrm{ClE}_{2}$. The ethinyl compounds $2-\mathrm{ClEE}_{2}$ and $4-\mathrm{ClEE}_{2}$ were administered orally. A dose one- or three-times molar equivalent to $\mathrm{EE}_{2}(16.5 \mu \mathrm{g} / \mathrm{rat} /$ day $)$ was used; 18 or $54 \mu \mathrm{g} / \mathrm{rat} /$ day for $2-\mathrm{ClEE}_{2}$ or $4-\mathrm{ClEE}_{2}$. The negative control rats received vehicle only. On day 4 , uterine horns were dissected and trimmed of fascia and fat. The uterine weight was measured after removing the luminal fluids on filter paper. Uterine wet-weight to body-weight (bw) ratios (mg/g bw) were compared with that obtained for the OVX-rats treated subcutaneously with $E_{2}(3.0 \mu \mathrm{g} / \mathrm{rat} /$ day $)$ as a positive control. Statistical analysis (one-way ANOVA with Tukey's post hoc test) was performed to evaluate the significance of the differences in treatment effects.

Author Contributions: Conceptualization, S.S.; Methodology, Y.O. and S.I.; Validation, Y.O., S.I. and S.S.; Formal Analysis, Y.O.; Investigation, Y.O. and S.I.; Resources, H.J. and S.I.; Data Curation, Y.O.; Writing—original draft preparation, S.S.; Writing—review and editing, Y.O., H.J. and S.I.; Visualization, Y.O. and S.S.; Project Administration, S.S.; Funding Acquisition, Y.O., H.J. and S.I. All authors have read and agreed to the published version of the manuscript.

Funding: This research was supported by a grant from Takeda Science Foundation (Japan).

Institutional Review Board Statement: The studies involving animals were conducted according to the guidelines of the Declaration of Helsinki, and approved by the Ethics Committee of Faculty of Pharmacy, Meijo University (protocol \#2012-P-E-24, 24 July 2012).

Informed Consent Statement: Not applicable.

Data Availability Statement: Not applicable.

Acknowledgments: We thank N. Suzuki and M. Mizukami for their technical assistance and Y. Shibutani for help in preparing the manuscript.

Conflicts of Interest: The authors declare no conflict of interest.

\author{
Abbreviations \\ $\mathrm{E}_{2} \quad 17 \beta$-estradiol \\ 2-OHE 2-hydroxyestrogen \\ 4-OHE 4-hydroxyestrogen \\ 2- $\mathrm{ClE}_{2}$ 2-chloro-17 $\beta$-estradiol \\ 4-ClE 2 4-chloro- $17 \beta$-estradiol
}




$\begin{array}{ll}\mathrm{EE}_{2} & 17 \alpha \text {-ethinylestradiol } \\ \text { 2-ClEE } & \text { 2-chloro-17 } \alpha \text {-ethinylestradiol } \\ \text { 4-ClEE } & \text { 4-chloro-17 } \alpha \text {-ethinylestradiol } \\ 2-\mathrm{FE}_{2} & \text { 2-fluoro-17 } \beta \text {-estradiol } \\ 4-\mathrm{FE}_{2} & \text { 4-fluoro-17 } \beta \text {-estradiol } \\ \mathrm{ACI} & \text { August Copenhagen Irish } \\ \mathrm{HRT} & \text { Hormone replacement therapy } \\ \mathrm{OVX} & \text { Ovariectomized } \\ \text { bw } & \text { Body weight } \\ \text { RIA } & \text { Radioimmunoassay }\end{array}$

\section{References}

1. Grodstein, F.; Stampfer, M.J.; Colditz, G.A.; Willett, W.C.; Manson, J.E.; Joffe, M.; Rosner, B.; Fuchs, C.; Hankinson, S.E.; Hunter, D.L.; et al. Postmenopausal hormone therapy and mortality. N. Engl. J. Med. 1997, 336, 1769-1775. [CrossRef] [PubMed]

2. Bolton, J.L.; Pisha, E.; Zhang, F.; Qiu, S. Role of quinoids in estrogen carcinogenesis. Chem. Res. Toxicol. 1998, 11, $1113-1127$. [CrossRef] [PubMed]

3. Colditz, G.A.; Hankinson, S.E.; Hunter, D.J.; Willett, W.C.; Manson, J.E.; Stampfer, M.J.; Hennekens, C.H.; Rosner, B.; Speizer, F.E. The use of estrogens and progestins and the risk of breast cancer in postmenopausal women. N. Engl. J. Med. 1995, 332, $1589-1593$. [CrossRef] [PubMed]

4. Chen, C.L.; Weiss, N.S.; Newcomb, P.; Barlow, W.; White, E. Hormone replacement therapy in relation to breast cancer. JAMA 2002, 287, 734-741. [CrossRef] [PubMed]

5. Lacey, J.V., Jr.; Mink, P.J.; Lubin, J.H.; Sherman, M.E.; Troisi, R.; Hartge, P.; Schatzkin, A.; Schairer, C. Menopausal hormone replacement therapy and risk of ovarian cancer. JAMA 2002, 288, 334-341. [CrossRef] [PubMed]

6. Beral, V. Million Women Study Collaborators. Breast cancer and hormone-replacement therapy in the Million Women Study. Lancet 2003, 362, 419-427. [CrossRef]

7. Grady, D.; Gebretsadik, T.; Kerlikowske, K.; Emster, V.; Petitti, D. Hormone replacement therapy and endometrial cancer risk: A meta-analysis. Obstet. Gynecol. 1995, 85, 304-313. [CrossRef]

8. Steinberg, K.K.; Smith, S.J.; Thacker, S.B.; Stroup, D.F. Breast cancer risk and duration of estrogen use: The role of study design in meta-analysis. Epidemiology 1994, 5, 415-421. [CrossRef]

9. Liehr, J.G. Genotoxic effects of estrogens. Mutat. Res. 1990, 238, 269-276. [CrossRef]

10. Fishman, J.; Osborne, M.P.; Telang, N.T. The role of estrogen in mammary carcinogenesis. Ann. N. Y. Acad. Sci. 1995, 768, 91-100. [CrossRef]

11. Hernandez, L.G.; Steeg, H.; Luijten, M.; Benthem, J. Mechanisms of non-genotoxic carcinogens and importance of a weight of evidence approach. Mutat. Res. 2009, 682, 94-109. [CrossRef]

12. Greenberg, E.R.; Barnes, A.B.; Resseguie, Z.; Barrett, J.A.; Burnside, S.; Lanza, L.L.; Neff, R.K.; Stevens, M.; Young, R.H.; Colton, T. Breast cancer in mothers given diethylstilbestrol in pregnancy. N. Engl. J. Med. 1984, 311, 1393-1398. [CrossRef]

13. Liehr, J.G.; Avitts, T.A.; Randerath, E.; Randerath, K. Estrogen-induced endogenous DNA adduction: Possible mechanism of hormonal cancer. Proc. Nalt. Acad. Sci. USA 1986, 83, 5301-5305. [CrossRef]

14. Gladek, A.; Liehr, J.G. Mechanism of genotoxicity of diethylstilbestrol in vivo. J. Biol. Chem. 1989, 264, 16847-16852. [CrossRef]

15. Preston-Martin, S.; Pike, M.C.; Ross, R.K.; Jones, P.A.; Henderson, B.E. Increased cell division as a cause of human cancer. Cancer Res. 1990, 50, 7415-7421.

16. Martucci, C.P.; Fishman, J. P450 enzymes of estrogen metabolism. Pharmac. Ther. 1993, 57, 237-257. [CrossRef]

17. Dwivedy, I.; Devanesan, P.; Cremonesi, P.; Rogan, E.; Cavalieri, E. Synthesis and characterization of estrogen 2,3- and 3,4-quinones. Comparison of DNA adducts formed by the quinones versus horseradish peroxidase-activated catechol estrogens. Chem. Res. Toxicol. 1992, 5, 828-833. [CrossRef]

18. Hayashi, N.; Hasegawa, K.; Komine, A.; Tanaka, Y.; McLachian, J.A.; Barrett, J.C.; Tsutsui, T. Estrogen-induced cell transformation and DNA adduct formation in cultured Syrian hamster embryo cells. Mol. Carcinog. 1996, 16, 149-156. [CrossRef]

19. Stack, D.E.; Byun, J.; Gross, M.L.; Rogan, E.G.; Cavalieri, E.L. Molecular characteristics of catechol estrogen quinone in reactions with deoxyribonucleosides. Chem. Res. Toxicol. 1996, 9, 851-859. [CrossRef]

20. Terashima, I.; Suzuki, N.; Shibutani, S. Mutagenic specificity of 2-hydroxyestrogen quinone-derived DNA adducts in mammalian cells. Biochemistry 2001, 40, 166-172. [CrossRef]

21. Li, K.M.; Todorovic, R.; Devanesan, P.; Higginbotham, S.; Köfeler, H.; Ramanathan, R.; Gross, M.L.; Rogan, E.G.; Cavalieri, E.L. Metabolism and DNA binding studies of 4-hydroxyestradiol and estradiol-3,4-quinone in vitro and in female ACI rat mammary gland in vivo. Carcinogenesis 2004, 25, 289-297. [CrossRef] [PubMed]

22. Takeshita, M.; Eisenberg, W. Mechanism of mutation on DNA templates containing synthetic abasic sites: Study with a double strand vector. Nucleic Acids Res. 1994, 22, 1897-1902. [CrossRef]

23. Han, X.; Liehr, J.G. 8-Hydroxylation of guanine bases in kidney and liver DNA of hamsters treated with estradiol: Role of free radicals in estrogen-induced carcinogenesis. Cancer Res. 1994, 54, 5515-5517. [PubMed] 
24. Malins, D.C.; Holmes, E.H.; Polissar, N.L.; Gunselman, S.J. The etiology of breast cancer. Characteristic alteration in hydroxyl radical-induced DNA base lesions during oncogenesis with potential for evaluating incidence risk. Cancer 1993, 71, $3036-3043$. [CrossRef]

25. Turan, V.K.; Sanchez, R.I.; Li, J.J.; Li, S.A.; Reuhl, K.R.; Thomas, P.E.; Conney, A.H.; Gallo, M.A.; Kauffman, F.C.; Mesia-Vela, S. The effects of steroidal estrogens in ACI rat mammary carcinogenesis: 17 $\beta$-estradiol, 2-hydroxyestradiol, 4-hydroxyestradiol, 16 $\alpha$-hydroxyestradiol, and 4-hydroxyestrone. J. Endocrinol. 2004, 183, 91-99. [CrossRef] [PubMed]

26. Shull, J.D.; Spady, T.J.; Snyder, M.C.; Johansson, S.L.; Pennington, K.L. Ovary-intact but not ovariectomized female ACI rats treated with $17 \beta$-estradiol rapidly develop mammary carcinoma. Carcinogenesis 1997, 18, 1595-1601. [CrossRef] [PubMed]

27. Okamoto, Y.; Jinno, H.; Itoh, S.; Shibutani, S. Carcinogenic potential of fluorinated estrogens in mammary tumorigenesis. Toxicol. Lett. 2020, 318, 99-103. [CrossRef]

28. Holtzman, S.; Stone, J.P.; Shellabarger, C.J. Synergism of estrogens and X-rays in mammary carcinogenesis in female ACI rats. J. Natl. Cancer Inst. 1981, 67, 455-459.

29. Kuhl, H. Pharmacology of estrogens and progestogens: Influence of different routes of administration. Climacteric 2005, 8 (Suppl. 1), 3-63. [CrossRef]

30. Stanczyk, F.Z.; Archer, D.F.; Bhavnani, B.R. Ethinyl estradiol and 17ß-estradiol in combined oral contraceptives: Pharmacokinetics, pharmacodynamics and risk assessment. Contraception 2013, 87, 706-727. [CrossRef]

31. Okamoto, Y.; Liu, X.; Suzuki, N.; Okamoto, K.; Kim, H.J.; Laxmi, Y.R.S.; Sayama, K.; Shibutani, S. Equine estrogen-induced mammary tumors in rats. Toxicol. Lett. 2010, 193, 224-228. [CrossRef]

32. Hu, J.; Cheng, S.; Aizawa, T.; Terao, Y.; Kunikanw, S. Products of aqueous chlorination of $17 \beta$-estradiol and their estrogenic activities. Envirion. Sci. Technol. 2003, 37, 5665-5670. [CrossRef]

33. Nakamura, H.; Shiozawa, T.; Terao, Y.; Shiraishi, F.; Fukazawa, H. By-products produced by the reaction of estrogens with hypochlorous acid and their estrogen activities. J. Heath Sci. 2006, 52, 124-131. [CrossRef]

34. Holtzman, S. Retinyl acetate inhibits estrogen-induced mammary carcinogenesis in female ACI rats. Carcinogenesis 1988, 9 , 305-307. [CrossRef]

35. Roberts, D.J.; Caserio, M.C. Basic Principles of Organic Chemistry; W. A. Benjamin Inc.: New York, NY, USA, $1965 ;$ Volume 77.

36. Ashburn, S.P.; Han, X.; Liehr, J.G. Microsomal hydroxylation of 2- and 4-fluoroestradiol to catechol metabolites and their conversion to methyl ethers: Catechol estrogens as possible mediators of hormonal carcinogenesis. Mol. Pharmacol. 1993, 43, 534-541.

37. Page, P.C.B.; Hussain, F.; Maggs, J.L.; Morgan, P.; Park, B.K. Efficient regioselective A-ring functionalization of oestrogens. Tetrahedron 1990, 46, 2059-2068. [CrossRef]

38. Mukawa, F. 10ß-Chloro-17 $\beta$-hydroxyestra-1,4-dien-3-one and its related compounds. J. Chem. Soc. Perkin Trans. 1988, 1, 457-460. [CrossRef] 